\title{
Yapay Zekâ ve İstatistiksel Yöntemler ile Küresel Ticarette Rekabet Ölçütü Olan Lojistik Performans İndeksine (LPI) Etken Parametrelerin Ülke Bazlı İncelenmesi ve Tahmin Modellerinin Geliştirilmesi
}

\author{
Ömer Faruk CANSIZ ${ }^{1}$, Kevser ÜNSALAN²* \\ 1-2* İnşaat Mühendisliği Bölümü, Mühendislik ve Doğa Bilimleri Fakültesi, İskenderun Teknik Üniversitesi, Hatay, \\ Türkiye \\ ${ }^{1}$ ofaruk.cansiz@iste.edu.tr, ${ }^{2}$ kevser.keskin@iste.edu.tr
}

\begin{abstract}
Öz: Firmalar ürettikleri ürünleri pazarlamak için birçok farklı yöntem geliştirmektedir. Ürünün, üreticiden tüketiciye ulaşana kadar sürecin her aşaması rekabet piyasasında incelenmesi gereken önemli birer unsur olmaktadır. İncelenen bu süreçler lojistik ana teması altında toplanmaktadır. Bu çalışmada ülkelerin lojistik alt yapısı hakkında önemli bilgi veren ve küresel ölçekte karşılaştırma imkânı sunan lojistik performans indeksi (LPI) kavramı incelenmektedir. LPI'ne etki eden parametreler gözden geçirilmekte ve bu bağlamda liman alt yapı kalitesi, layner taşımacılığı, gümrük giderleri, havayolu yük taşımacılığı, ihracat miktarı değişkenleri incelenmektedir. Bu değişkenlerin LPI ile ilişkisi istatistiksel olarak ele alınmaktadır. Çalışmanın son aşamasında ise istatistiksel olarak anlamlı olan girdiler göz önünde bulundurularak sayısal veriler ışığında LPI için yapay zekâ ve çok değişkenli lineer regresyon (MLR) yöntemleri kullanılarak tahmin modelleri geliştirilmektedir.
\end{abstract}

Anahtar kelimeler: Lojistik performans indeksi, yapay zekâ, YSA, ANFIS, regresyon

\section{Prediction of Logistics Performance Index by Analysis of Effective Parameters on LPI Based on Countries, Which is Competition Criterion in Global Trade by Using Artificial Intelligence and Statistical Methods}

\begin{abstract}
Companies develop many different methods to market the products they produce. Every stage of the product, from the manufacturer to the consumer, is an important element that must be examined in the competitive market. These processes are gathered under the main theme of logistics. In this study, logistics performance index (LPI), which gives important information about the logistics infrastructure of the countries and offers the opportunity to compare globally, is examined. Parameters affecting LPI are reviewed and along with the variables of port infrastructure quality, liner transportation, customs expenses, airline freight transportation, export amount. The relationship of these variables with LPI is considered statistically. In the last stage of the study, considering the statistically significant inputs, prediction models are developed using artificial intelligence and multiple linear regression (MLR) methods in the light of numerical data.
\end{abstract}

Key words: Logistics performance index, artificial intelligence, ANN, ANFIS, regression

\section{Giriş}

Lojistik, üretici ve tüketici arasındaki sirkülasyonun koordinasyonu ile ilgilenmektedir. Lojistik hizmetler; ürünün kabulü, depolanması, stok yönetimi, siparişin hazırlanması ve sevkiyatın sağlanmasından meydana gelmektedir [1]. Küresel ticaretin artışı ile beraber, lojistik sektörünün önemi ön plana çıkmaktadır. Sektörel büyümenin artışı ile ülkelerin küresel ölçekte lojistik performansları hakkında bilgi sahibi olmaları büyük önem arz etmektedir. Lojistik sektörü bakımından gelişmiş ülkeler daha rekabetçi davranmakta ve kar marjlarını yükseltmektedir [2]. Bu nedenle ülkelerin lojistik performansları hakkında bilgi sahibi olmaları ve küresel ölçekte yerini bilerek gelişimini sağlaması oldukça önemlidir. Dünya Bankası'nın iki yılda bir yayınladığı altı indikatöre bağlı olarak hesaplanan lojistik performans indeksi (LPI), ülkelerin lojistik sektörü açısından yerinin bilinmesinde önemli bir ölçüt olmaktadır [3]. LPI, ülkelerin gümrük işlemleri, lojistik maliyetleri, ulaşım altyapısı bakımından ülkeler arasındaki farklılıkları ortaya çıkarmaktadır [4]. LPI belirlenirken kıstas olarak alınan indikatörler eşit ağırlıklı olarak dikkate alınmaktadır. Temelde her indikatörün farklı ağırlıklarla etki etmesi gerekmektedir. Bunun için literatürde öznel ve nesnel ağırlıklandırma metotları mevcuttur [5]. LPI etken parametrelerin ağırlıklarının

\footnotetext{
* Sorumlu yazar: kevser.keskin@ @iste.edu.tr. Yazarların ORCID Numaras1: ${ }^{1}$ 0000-0001-6857-2513, ${ }^{2}$ 0000-0002-9163-4855
} 
belirlenmesinin yanında etken parametrelerinde belirlenmesi oldukça önemlidir. Lojistik sektöründe etken girdilerin incelenmesi üzerine çalışmalar yapılmaktadır. Başar ve Bozma havuzlanmış panel veri analizi kullanılarak LPI'ne etken makro düzeyde ekonomik ve politik faktörleri araştırmaktadır [6].

Güner ve Coşkun çalışmalarında ülkelerin rekabet gücünü önemli ölçüde etkileyen sosyal ve ekonomik değişkenlerin LPI değişimi üzerine etkilerini araştırmaktadır [7]. Bir başka çalışmada LPI'nin alt indekslerinin gayri safi milli hâsıla üzerindeki etkisi incelenmektedir [8]. Karaköy ve Üre yüksek ve orta gelirli ülkelerin gelişiminin LPI ile ilişkisini ortaya koymaktadır [9]. Bir başka çalışmada ülkedeki nitelikli iş gücünün arttırılmasının LPI üzerine etkileri analiz edilmektedir[10].

Bu çalışmada LPI ve etken indikatörler üzerinde durulmaktadır. Çalışmanın birinci aşamasında LPI üzerinde etkili olan parametreler istatistiksel olarak incelenmektedir. İkinci aşamada belirlenen parametrelere göre ülkeler klasik sınıflandırma metodu dikkate alınarak sınıflandırılmaktadır. Çalışmanın son aşamasında ise korelasyon analizi sonuçlarına göre LPI belirlemede $\alpha=0,05$ anlamlılık düzeyinde etkili olan parametreler dikkate alınarak LPI tahmin modelleri oluşturulmaktadır. Tahmin modellemesinde yapay zekâ tekniklerinden uyarlanabilir sinirsel bulanık çıkarım sistemi (ANFIS) ve yapay sinir ağları (YSA) yöntemi kullanılmaktadır. İstatistiksel metotlardan ise MLR tekniği olan doğrusal, etkileşimli, karesel ve basit karesel yöntemleri kullanılmaktadır. Tahmin modellerinin karşılaştırılmasında hataların karesinin ortalaması (HKO), ortalama yüzde hata $(\mathrm{OYH})$ ve korelasyon (R) performans kriterleri kullanılmaktadır.

\section{Materyal ve Metot}

\subsection{Materyal}

Bu çalışmada Liman altyapı kalitesi (Quality of Port Infrastructure-QPI), layner taşımacılığı bağlantı endeksi (Liner Shipping Connectivity Index-LSCI), gümrük giderleri (Burden of Customs Procedure-BCF), hava yolu yük taşımacılığı (Air Transport-AT), ticari hizmet ihracatı (Commercial Service Exports-CSE), gıda ihracatı (Food Export-FE), imalat ihracatı ( Manufactures exports-MAE), mal ihracatı (Merchandise Exports-MEE), değişkenleri kullanılarak LPI tahmin modellemesi yapılmaktadır. En son yayınlanan LPI verisinin 2016 yilında yayınlanmasından dolayı, bu yıldaki veriler dikkate alınarak modelleme yapılmaktadır.

Liman altyapı kalitesi (QPI), şirket yöneticilerinin ülkelerindeki liman tesislerine ilişkin algılarını ölçmektedir. Veriler, Dünya Ekonomik Forumu'nun 150 ortak kuruluşla birlikte yürüttüğü anket çalışması sonucu elde edilmektedir. Şirketlerin büyüklüğü ve sektördeki faaliyetleri esas alınarak QPI verileri toplanmaktadır. Veriler yüz yüze veya çevrimiçi olarak toplanmaktadır. Denize kıyısı olmayan yani limanı bulunmayan ülkelere ise liman tesislerinin ne seviyede erişebilir olduğu sorulmaktadır. Puanlar 1 ile 7 arasında değişim göstermektedir [11]. Layner taşımacılığı bağlantı endeksi (LSCI), ülkelerin küresel ölçekte deniz ağlarına ne kadar iyi bağlandığı gösteren bir endekstir. Deniz taşımacılığı sektörünün beş ana bileşeni olan gemi sayısı, konteyner taşıma kapasitesi, maksimum gemi büyüklüğü, hizmet sayısı ve konteyner kullanan şirket sayısı dikkate alınarak Birleşmiş Milletler Ticaret ve Kalkınma Konferansı (UNCTAD) tarafından hesaplanmaktadır. Her bir bileşen için o yılın her bir bileşeninin maksimum değerine bölünür. Beş bileşenin her ülke için ortalaması alınır ve ortalama o yıl için maksimum ortalamaya bölünür ve 100 ile çarpılır [12].

Gümrük giderleri (BCF), şirketlerin gümrük prosedürlerinin etkinliği konusundaki algılarını ölçmektedir. Veriler Dünya Ekonomik Forumu'nun 150 ortak kuruluşla yürüttüğü anket çalışması sonucu elde edilmektedir. Değerlendirme şirketlerin büyüklüğüne ve faaliyet sektörüne göre farklılık göstermektedir. Katılımcılar ülkelerindeki gümrük prosedürlerinin etkinliğini değerlendirmektedir. Puanlar 1'den 7'ye kadar en verimsizden en verimliye doğru artmaktadır [13]. Havayolu yük taşımacılığı (AT), hava yolu taşımacılığında her bir uçuşta, bir uçağın kalkıştan bir sonraki inişe kadar süreçte, kat edilen kilometre cinsinden taşınan yükün hacmidir [14]. Ticari hizmet ihracatı (CSE), toplam hizmet ithalatı ile başka bir yerde yer almayan devlet hizmetleri ihracatıdır. IMF'nin ödemeler dengesi el kitabında, aynı anda üretilebilen, aktarılabilen ve tüketilebilen maddi olmayan malların ekonomik çıktısı olarak tanımlanmaktadır[15]. Tanımlar, farklı ekonomiler arasında farklılık göstermektedir [16].

Gıda ihracatı (FE), Standart Uluslararası Ticaret Sınıflandırmasının (SITC) gıda ürünlerini hayvansal, bitkisel, içecek, tohum, çekirdek, sebze vb. sınıflandırmasına göre ülkelerin gıda ihracatının toplam ihracata oranını göstermektedir [17]. Sanayi ürünleri ihracatı (MAE), STIC tarafından ülkelerin sanayi ürünleri; makine ve nakliye ekipmanları, temel sanayi ürünleri, demir dışı metaller, kimyasallar, çeşitli sanayi ürünleri olmak üzere sınıflandırılarak hesaplanmaktadır [18]. Mal ihracatı (MEE), ülkelere göre gemide teslim edilen mal ticareti miktarını göstermektedir. Ekonomiye giren veya çıkan malların miktarı, gümrük raporlarından veya finansal işlem raporlarından elde edilmektedir [19]. Lojistik performans indeksi (LPI), bir ülkenin lojistiğinin; gümrükleme sürecinin etkinliği, Ticaret ve ulaştırma ile ilgili altyapının kalitesi, rekabetçi fiyatlar düzenleme kolaylı̆̆ı, lojistik 
hizmetlerin kalitesi, sevkiyatları izleme kalitesi, planlanan süre içerisinde gönderilerin alıcıya ulaşma sıklığına göre 1'den 5'e kadar puanlanması ile elde edilmektedir.

Ülkelerin LPI puanları, Dünya Bankası (WB) tarafından akademik, uluslararası kurumlar, özel şirketler ve uluslararası lojistikle uğraşan kişilerle ortaklaşa yürütülen anketler dikkate alınarak belirlenmektedir[20]. Çalışmada LPI, sekiz farklı parametre esas alınarak incelenmektedir. İstatistiksel incelemeler 85 farklı ülke baz alınarak yapılmaktadır. Verilerde karşılaştırma, sınıflandırma yapılabilmesi ve tahmin modellerinin geliştirilebilmesi için logaritmik transformasyon uygulanarak datalar normal dağılıma uygun hale getirilmektedir. Dataların $\log (x+1)$ transformasyonu sonrası ülkelere göre değişimi şekil 1'de verilmektedir [21].

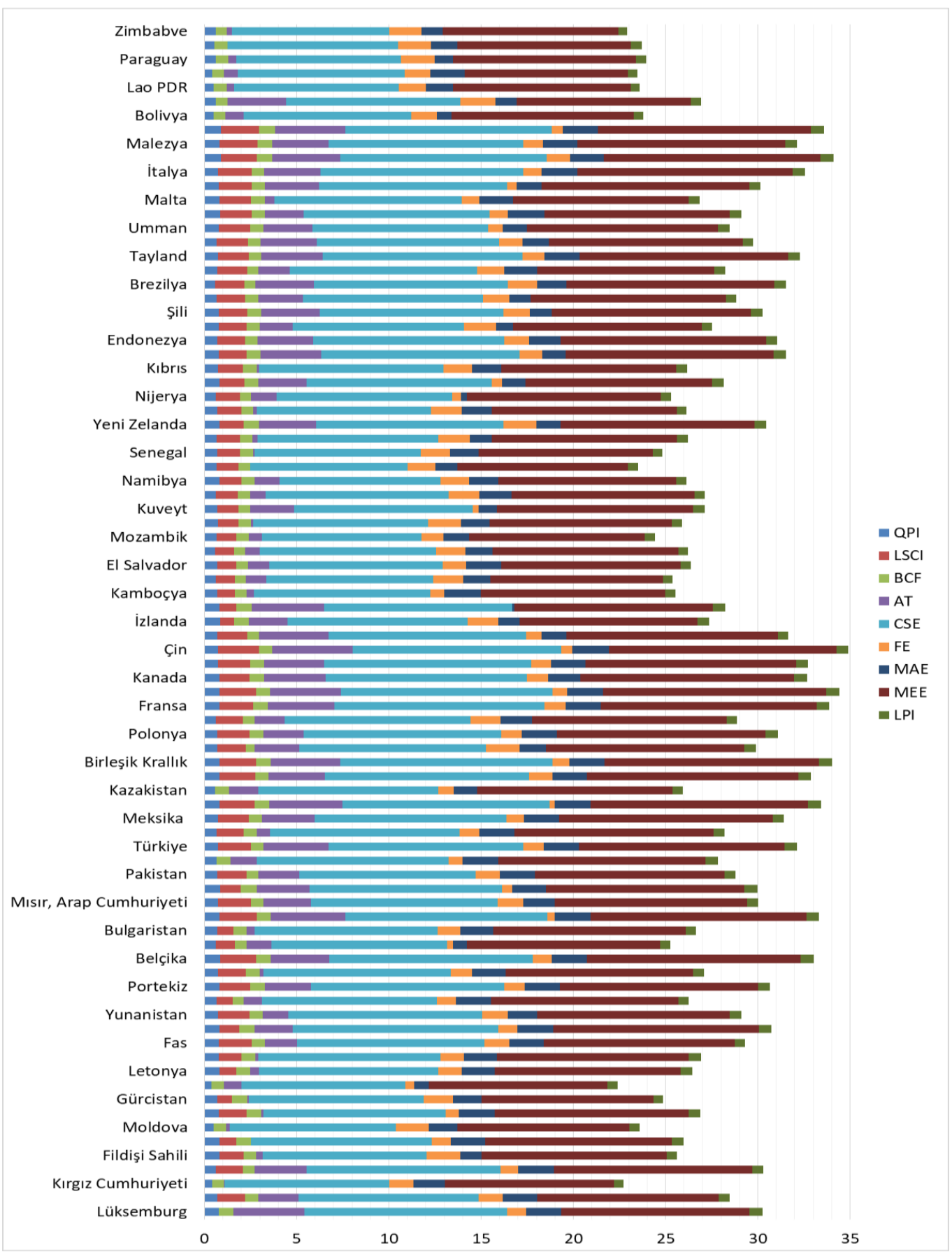

Şekil 1. LPI ve etken parametrelerin ülkelere göre değişimi 
Tablo 1'de incelenen parametrelerin özet istatistikleri verilmektedir. Analiz edilen 85 ülkenin QPI' s1 1,4 ile 6,8 arasında değişmektedir. Ortalaması ve standart sapması 4,26 $\pm 1,20$ ve varyasyon katsayısı $\% 28,11$ 'dir. Analiz edilen ülkelerin \%25'inin QPI değeri 3,45 ile ortalamanın altındadır. \%75'inin ise QPI değeri 5,2'nin altındadır. LSCI değerlerine bakıldığında 0 ile 169,2 aralığında değişmektedir. 0 değerini alan ülkelere bakıldığında denize kıyısı olmayan ülkeler olduğu görülmektedir. $\mathrm{Bu}$ da o ülkelerde layner taşımacılığının yapılamadığı

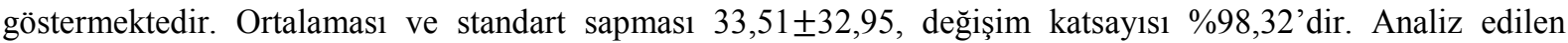
ülkelerin \%25'inin LSCI değerleri 8,89'dan , \%75'inin ise 49,45'den düşük olduğu görülmektedir.

Ülkelerin BCF değerleri incelendiğinde 2,1 ile 6,2 aralığında değişiklik göstermekte, ortalama ve standart sapması 4,16 $\pm 0,84$ 'tür. Verilerin varyasyon katsayısı \%20,11'dir. BCF değerlerinin \%25'inin 3,5'den, \% 75 'inin ise 4,75'ten düşük olduğu görülmektedir. AT değerleri incelendiğinde 0,003 ile 21304,59 milyon ton-km aralığında olduğu görülmektedir. Hava yolu yük taşımacılığı hacminin ülkelere göre ortalaması ve standart

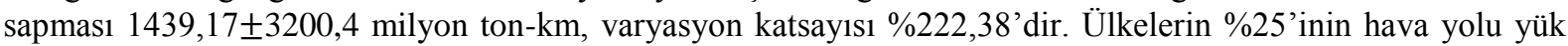
taşımacılığı hacmi 2,30 milyon ton $-\mathrm{km}$ den, \%75'inin ise 1190,87 milyon ton-km'den düşük olduğu belirlenmektedir. Ayrıca At değerlerine göre ülkelerin \%75'inin ortalamanın altında aldığı görülmektedir. CSE değerlerine bakıldığında 317000000 \$ ile $34500000000 \$$ aralığında değişmektedir. Ülkelerin ortalaması ve standart sapmas1 $39500000000 \$ \pm 68300000000 \$$, varyasyon katsayıs1 \%172,68 ç1kmaktadır. Analiz edilen ülkelerinin \%25'inin CSE değerlerinin 3110000000\$'dan düşük \%25'inin ise 34200000000\$ dan yüksek olduğu görülmüştür.

Ülkelerin FE değerleri analiz edildiğinde \%2 ile \%83,82 oranında değişim göstermektedir. FE oranının

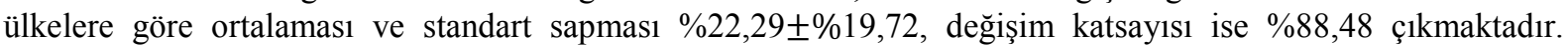
Ülkelerin \%25'inin FE oranının \%7,69'dan düşük, \%75'inin ise \%33,42'den düşük olduğu analiz edilmektedir. Ülkelerin sanayi ürünlerinin ihracattaki payı \%0,38 ile \%93,76 aralığında değişmektedir. MAE değerlerinin kıstas alınan 85 ülkeye göre ortalaması ve standart sapması $\% 49,42 \pm \% 29,25$, varyasyon katsay1s1 ise $\% 59,19$ çıkmaktadır. Analiz edilen ülkelerin \%25'inin MAE oranı \%20,11'den düşük, \%75'inin ise \%78,23'den düşük çıkmaktadır. MEE değerlerine bakıldığında en az MEE 696000000\$, en fazla ise $2100000000000 \$$ olduğu görülmektedir. Ülkelerin MEE ortalaması ve standart sapması 138000000000\$年 $295000000000 \$$, değişim katsayısı ise \% 213,36 çıkmaktadır. Ülkelerin \%25'inin MEE değeri 7750000000\$ dan, \%75'inin ise 173000000000 \$ dan düşük olduğu görülmektedir. Ülkelerin LPI değerleri incelendiğinde 2,07 ile 4,23 aralığında

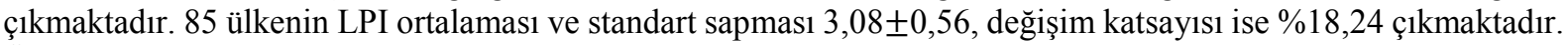
Ülkelerin \%25'inin LPI değeri 2,64'ten \%75'inin ise 3,42'den düşük olduğu belirlenmektedir.

Tablo 1. LPI ve etken parametrelerin özet istatistikleri

\begin{tabular}{l|lllllllll}
\hline \multicolumn{1}{l}{} & QPI & LSCI & $B C F$ & $A T$ & $C S E$ & $F E$ & $M A E$ & $M E E$ & $L P I$ \\
\hline$N$ & 85 & 85 & 85 & 85 & 85 & 85 & 85 & 85 & 85 \\
Min & 1,4 & 0 & 2,1 & 0,003 & $3,17 \mathrm{E}+08$ & 0,02747 & 0,382269 & $6,96 \mathrm{E}+08$ & 2,067254 \\
Max & 6,8 & 169,2 & 6,2 & 21304,59 & $3,45 \mathrm{E}+11$ & 83,82269 & 93,75454 & $2,10 \mathrm{E}+12$ & 4,225967 \\
Mean & 4,255294 & 33,51153 & 4,161176 & 1439,168 & $3,95 \mathrm{E}+10$ & 22,29044 & 49,41816 & $1,38 \mathrm{E}+11$ & 3,081765 \\
Std. error & 0,129722 & 3,573615 & 0,09075 & 347,1321 & $7,41 \mathrm{E}+09$ & 2,139095 & 3,172479 & $3,20 \mathrm{E}+10$ & 0,060983 \\
Variance & 1,430359 & 1085,512 & 0,700022 & $1,02 \mathrm{E}+07$ & $4,66 \mathrm{E}+21$ & 388,9367 & 855,4932 & $8,72 \mathrm{E}+22$ & 0,31611 \\
Stand. dev & 1,195976 & 32,9471 & 0,836673 & 3200,4 & $6,83 \mathrm{E}+10$ & 19,72148 & 29,24882 & $2,95 \mathrm{E}+11$ & 0,562237 \\
25 prcntil & 3,45 & 8,885 & 3,5 & 2,2995 & $3,11 \mathrm{E}+09$ & 7,690892 & 20,11319 & $7,75 \mathrm{E}+09$ & 2,63853 \\
75 prcntil & 5,2 & 49,445 & 4,75 & 1190,866 & $3,42 \mathrm{E}+10$ & 33,42057 & 78,23348 & $1,73 \mathrm{E}+11$ & 3,424785 \\
Skewness & $-0,19719$ & 1,489061 & 0,282235 & 3,783544 & 2,549824 & 1,134739 & $-0,1079$ & 4,518782 & 0,288052 \\
Kurtosis & $-0,26132$ & 2,765624 & $-0,38142$ & 18,17265 & 6,712543 & 0,490721 & $-1,4954$ & 25,40394 & $-0,75861$ \\
Coeff. var & 28,1056 & 98,31573 & 20,10666 & 222,3785 & 172,678 & 88,47505 & 59,18637 & 213,3608 & 18,24398 \\
\hline
\end{tabular}




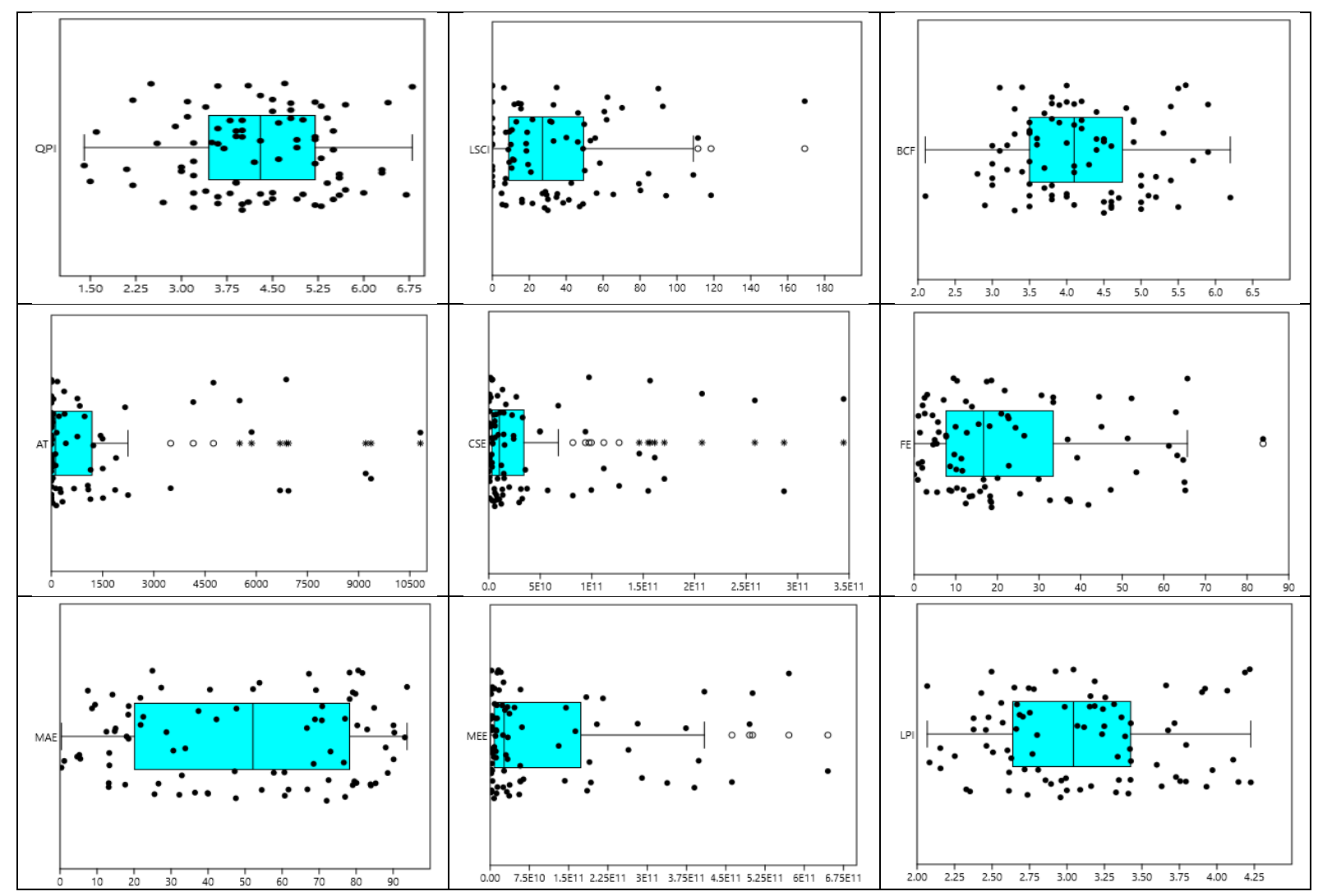

Şekil 2. Parametrelerin box-jitter grafikleri

Verilerin çarpıklık katsayısı incelendiğinde LSCI, AT, CSE, FE ve MEE parametrelerinin normal dağılıma uygun olmadığını göstermektedir. Bu da veriler için transformasyon yapılmasının gerekliliğini göstermektedir. Şekil 2'de parametrelerin ham değerleri esas alınarak box-jitter dağılımları verilmektedir. Grafiklere göre LSCI, AT, CSE, FE, MEE parametrelerinin sağa çarpık olduğu açık bir şekilde görülmektedir. QPI, BCF, MAE ve LPI parametrelerinin ise medyan değerinin kutuyu simetriğe yakın ayırmasından dolayı normal dağılıma yakın olduğu görülmektedir.

LPI ve değişkenler arasında $\alpha=0,05$ anlamlılık düzeyinde farklılık olup olmadığının testi için öncelikle varyansların homojenliği testi için F testi uygulanmaktadır. Varyans homojenliği testinde Ho hipotezi, $\sigma_{1}{ }^{2}=\sigma_{2}{ }^{2}$ ise varyanslar homojendir, değil ise heterojen olması üzerine kurulmaktadır. Tablo 2 de varyans homojenliğinin test edilmesi için F testi sonuçları verilmektedir. Tabloda her bir değişkenin $p$ değerleri incelendiğinde $\alpha=0,05$ ve $\alpha=0,01$ anlamlılık düzeyinde Ho hipotezinin red edildiği görülmektedir. Yani tüm değişkenler ve LPI arasında varyansların heterojen olduğu söylenebilmektedir. Bu durumda varyansların heterojen olması koşuluna göre değişkenler için t testi uygulanmakta ve sonuçlar tablo 3 'te verilmektedir. T testi için Ho hipotezi, LPI ve değişken parametrelerin ortalaması arasında fark olmaması üzerine kurulmaktadır. Tablodaki p değerleri incelendiğinde hem $\alpha=0,05$ hem de $\alpha=0,01$ anlamlılık düzeyinde değişkenler ve LPI değerlerinin arasında önemli derecede fark olduğu açık bir şekilde görülmektedir.

Tablo 2. LPI ve değişkenler arasında varyansların homojenliği için F testi

\begin{tabular}{|c|c|c|c|c|c|c|c|c|c|}
\hline & QPI & LSCI & $\mathrm{BCF}$ & AT & CSE & $\mathrm{FE}$ & MAE & MEE & LPI \\
\hline Ortalama & 4,255294 & 33,51153 & 4,161176 & 1439,168 & $3,95 \mathrm{E}+10$ & 22,29044 & 49,41816 & $1,38 \mathrm{E}+11$ & 3,081765 \\
\hline Varyans & 1,430359 & 1085,512 & 0,700022 & 10242562 & $4,66 \mathrm{E}+21$ & 388,9367 & 855,4932 & $8,72 \mathrm{E}+22$ & 0,31611 \\
\hline Gözlem & 85 & 85 & 85 & 85 & 85 & 85 & 85 & 85 & 85 \\
\hline df & 84 & 84 & 84 & 84 & 84 & 84 & 84 & 84 & 84 \\
\hline $\mathrm{F}$ & 4,524874 & 3433,967 & 2,214489 & 32401876 & $1,48 \mathrm{E}+22$ & 1230,384 & 2706,314 & $2,76 \mathrm{E}+23$ & \\
\hline $\mathrm{P}(\mathrm{F}<=\mathrm{f})$ tek-uçlu & $1,96 \mathrm{E}-11$ & $2,6 \mathrm{E}-125$ & 0,000168 & 3E-292 & 0 & $1,3 \mathrm{E}-106$ & $5,6 \mathrm{E}-121$ & 0 & \\
\hline F Kritik iki-uçlu & 1,434729 & 1,434729 & 1,434729 & 1,434729 & 1,434729 & 1,434729 & 1,434729 & 1,434729 & \\
\hline
\end{tabular}


Yapay Zekâ ve İstatistiksel Yöntemler ile Küresel Ticarette Rekabet Ölçütü Olan Lojistik Performans İndeksine (LPI) Etken Parametrelerin Ülke Bazlı İncelenmesi ve Tahmin Modellerinin Geliştirilmesi

Tablo 3. LPI ve değişkenler arasında varyansların heterojen olması durumuna göre t testi

\begin{tabular}{|c|c|c|c|c|c|c|c|c|c|}
\hline & QPI & LSCI & $\mathrm{BCF}$ & AT & CSE & $\mathrm{FE}$ & MAE & MEE & LPI \\
\hline Ortalama & 4,255294 & 33,51153 & 4,161176 & 1439,168 & $3,95 \mathrm{E}+10$ & 22,29044 & 49,41816 & $1,38 \mathrm{E}+11$ & 3,081765 \\
\hline Varyans & 1,430359 & 1085,512 & 0,700022 & 10242562 & $4,66 \mathrm{E}+21$ & 388,9367 & 855,4932 & $8,72 \mathrm{E}+22$ & 0,31611 \\
\hline Gözlem & 85 & 85 & 85 & 85 & 85 & 85 & 85 & 85 & 85 \\
\hline Öngörülen Ortalama Fark1 & 0 & 0 & 0 & 0 & 0 & 0 & 0 & 0 & \\
\hline df & 119 & 84 & 147 & 84 & 84 & 84 & 84 & 84 & \\
\hline t Stat & 8,186964 & 8,513881 & 9,872366 & 4,137002 & 5,339156 & 8,976168 & 14,60304 & 4,321105 & \\
\hline $\mathrm{P}(\mathrm{T}<=\mathrm{t})$ tek-uçlu & $1,71 \mathrm{E}-13$ & $2,82 \mathrm{E}-13$ & $2,99 \mathrm{E}-18$ & $4,16 \mathrm{E}-05$ & $3,91 \mathrm{E}-07$ & $3,31 \mathrm{E}-14$ & $4,53 \mathrm{E}-25$ & $2,12 \mathrm{E}-05$ & \\
\hline t Kritik tek-uçlu & 1,657759 & 1,663197 & 1,655285 & 1,663197 & 1,663197 & 1,663197 & 1,663197 & 1,663197 & \\
\hline $\mathrm{P}(\mathrm{T}<=\mathrm{t})$ iki-uçlu & $3,42 \mathrm{E}-13$ & $5,65 \mathrm{E}-13$ & $5,98 \mathrm{E}-18$ & $8,31 \mathrm{E}-05$ & $7,82 \mathrm{E}-07$ & $6,63 \mathrm{E}-14$ & $9,06 \mathrm{E}-25$ & $4,24 \mathrm{E}-05$ & \\
\hline t Kritik iki-uçlu & 1,9801 & 1,98861 & 1,976233 & 1,98861 & 1,98861 & 1,98861 & 1,98861 & 1,98861 & \\
\hline
\end{tabular}

Değişkenler arasındaki çapraz korelasyon ilişkisi Tablo 4'te verilmektedir. $\alpha=0,05$ anlamlılık düzeyinde LPI ile diğer değişkenler arasında anlamlı bir ilişki olduğu görülmektedir. Bu nedenle LPI tahmin modellerinin oluşturulmasında tüm değişkenler dikkate alınmaktadır. LPI ile en güçlü ilişki CSE arasında çıkmaktadır. En zayıf ilişki ise \%39,2 ile MAE parametresinde görülmektedir. FE parametresi ve LPI arasında ise negatif ilişki görülmektedir. Bu da günümüzde tarım ve hayvancılık ülkesi olmanın lojistik performans indeksini düşürdüğünü göstermektedir.

Tablo 4. Parametrelerin çapraz korelasyon değerleri

\begin{tabular}{|c|c|c|c|c|c|c|c|c|c|}
\hline & QPI & LSCI & BCF & AT & CSE & FE & MAE & MEE & LPI \\
\hline QPI & & 0,65817 & 0,66431 & 0,47151 & 0,58328 & $-0,24587$ & 0,30318 & 0,50528 & 0,73054 \\
\hline LSCI & 0,65817 & & 0,22726 & 0,53709 & 0,64338 & $-0,25642$ & 0,36073 & 0,65043 & 0,52714 \\
\hline BCF & 0,66431 & 0,22726 & & 0,34151 & 0,50721 & $-0,30764$ & 0,24497 & 0,36284 & 0,69665 \\
\hline AT & 0,47151 & 0,53709 & 0,34151 & & 0,76243 & $-0,42696$ & 0,14195 & 0,78363 & 0,66826 \\
\hline CSE & 0,58328 & 0,64338 & 0,50721 & 0,76243 & & $-0,41727$ & 0,501 & 0,86619 & 0,83804 \\
\hline FE & $-0,24587$ & $-0,25642$ & $-0,30764$ & $-0,42696$ & $-0,41727$ & & $-0,00975$ & $-0,49437$ & $-0,47316$ \\
\hline MAE & 0,30318 & 0,36073 & 0,24497 & 0,14195 & 0,501 & $-0,00975$ & & 0,30859 & 0,39206 \\
\hline MEE & 0,50528 & 0,65043 & 0,36284 & 0,78363 & 0,86619 & $-0,49437$ & 0,30859 & & 0,74805 \\
\hline LPI & 0,73054 & 0,52714 & 0,69665 & 0,66826 & 0,83804 & $-0,47316$ & 0,39206 & 0,74805 & \\
\hline
\end{tabular}

Ülkeler arasındaki benzerlikleri ve farklılıkları ortaya koymak amacıyla, klasik kümeleme ve SIMPER (Similarity Percentage) analizleri yapılmaktadır. Kümeleme analizinde aritmetik ortalama ile ağırlıksız çift grup algoritması (UPGMA) ve Chord benzerlik indeksi kullanılmaktadır. QPI, LSCI, BCF, AT, CSE, FE, MAE, MEE ve LPI parametreleri dikkate alınarak Tablo 5'teki gibi sınıflandırılmaktadır. Sınıflandırmanın kofenetik korelasyon katsayıs1 \%80,54 (Cofen. Corr.=0,8054) bulunmaktadır. SIMPER analizi, her parametrenin ülkeler arasındaki farklılığa yol açma oranlarını belirlemede kullanılmaktadır. Analizde Chord benzerlik ölçütü kullanılmaktadır. Analiz sonuçları Tablo 6'da verilmektedir. Ülkelerin sınıflandırılmasında en fazla katkıyı $\% 65,16$ oraniyla AT parametresi vermektedir.

Tablo 5. Ülkelerin değişkenlere göre sınıflandırılması

\begin{tabular}{|c|c|c|c|c|c|c|}
\hline A1 & A21 & A221 & A222 & B1 & B21 & B22 \\
\hline Katar & $\begin{array}{l}\text { Lüksemburg, } \\
\text { Etiyopya }\end{array}$ & $\begin{array}{l}\text { Filipinler, Belçika, Kore } \\
\text { Cumhuriyeti, Misır, Arap } \\
\text { Cumhuriyeti, Finlandiya, } \\
\text { Türkiye, Meksika, Japonya, } \\
\text { İspanya, Birleşik Krallı,, } \\
\text { Fransa, Almanya, Kanada, } \\
\text { Hindistan, Çin, Rusya, } \\
\text { Kuveyt, Bahreyn, } \\
\text { Avustralya, Endonezya, Şili, } \\
\text { Brezilya, Tayland, } \\
\text { Kolombiya, Umman, Suudi } \\
\text { Arabistan, İtalya, Hollanda, } \\
\text { Malezya, Singapur }\end{array}$ & $\begin{array}{l}\text { Ürdün, Fas, İrlanda, } \\
\text { Yunanistan, } \\
\text { Portekiz, Pakistan, } \\
\text { Arjantin, Polonya, } \\
\text { Ukrayna, İzlanda, } \\
\text { Namibya, Y Yeni } \\
\text { Zelanda, Ekvador, } \\
\text { Peru, } \\
\text { Panama }\end{array}$ & $\begin{array}{l}\text { Moğolistan, } \\
\text { Cezayir, Çek } \\
\text { Cumhuriyeti, } \\
\text { Kazakistan, } \\
\text { Nijerya, } \\
\text { Bolivya }\end{array}$ & $\begin{array}{l}\text { Kurgız } \\
\text { Cumhuriyeti, } \\
\text { Moldova, Lao } \\
\text { PDR, Nepal, } \\
\text { Paraguay, } \\
\text { Uganda, } \\
\text { Zimbabve }\end{array}$ & $\begin{array}{l}\text { Fildişi Sahili, } \\
\text { Estonya, Slovenya, } \\
\text { Gürcistan, } \\
\text { Letonya, Litvanya, } \\
\text { Tunus, Hırvatistan, } \\
\text { Bulgaristan, } \\
\text { Romanya, } \\
\text { Kamboçya, } \\
\text { Madagaskar, El } \\
\text { Salvador, } \\
\text { Myanmar, } \\
\text { Mozambik, } \\
\text { Honduras, Kosta } \\
\text { Rika, } \\
\text { Senegal, Benin, Gana, } \\
\text { Guatemala, Kibris, } \\
\text { Malta }\end{array}$ \\
\hline
\end{tabular}


Tablo 6. SIMPER analizine göre parametrelerin sınıflandırmaya katkıları

\begin{tabular}{|c|c|c|c|c|c|c|c|c|c|c|}
\hline Taxon & $\begin{array}{l}\text { Av. } \\
\text { dissim }\end{array}$ & $\begin{array}{l}\text { Contrib. } \\
\%\end{array}$ & $\begin{array}{l}\text { Cumulati } \\
\text { ve } \%\end{array}$ & $\begin{array}{l}\text { Mean } \\
\text { A21 }\end{array}$ & $\begin{array}{l}\text { Mean } \\
\text { A222 }\end{array}$ & $\begin{array}{l}\text { Mean } \\
\text { B21 }\end{array}$ & $\begin{array}{l}\text { Mean } \\
\text { A221 }\end{array}$ & $\begin{array}{l}\text { Mean } \\
\text { B22 }\end{array}$ & $\begin{array}{l}\text { Mean } \\
\text { B1 }\end{array}$ & $\begin{array}{l}\text { Mean } \\
\text { A1 }\end{array}$ \\
\hline $\mathbf{A T}$ & 0,01676 & 65,16 & 65,16 & 3,51 & 2,06 & 0,298 & 3,26 & 0,431 & 1,29 & 3,96 \\
\hline LSCI & 0,003837 & 14,92 & 80,08 & 0 & 1,49 & 0 & 1,73 & 1,17 & 0,4 & 0,913 \\
\hline FE & 0,002515 & 9,778 & 89,86 & 1,47 & 1,42 & 1,63 & 0,955 & 1,35 & 0,707 & 0,0118 \\
\hline MAE & 0,001382 & 5,373 & 95,23 & 1,52 & 1,62 & 1,44 & 1,71 & 1,65 & 0,989 & 0,141 \\
\hline MEE & 0,000597 & 2,319 & 97,55 & 9,83 & 10,4 & 9,4 & 11,3 & 9,92 & 10,4 & 10,8 \\
\hline CSE & 0,000489 & 1,903 & 99,45 & 10,2 & 10 & 8,94 & 10,7 & 9,57 & 9,52 & 10,2 \\
\hline QPI & $8,69 \mathrm{E}-05$ & 0,3378 & 99,79 & 0,69 & 0,747 & 0,515 & 0,765 & 0,703 & 0,555 & 0,82 \\
\hline BCF & $4,30 \mathrm{E}-05$ & 0,1672 & 99,96 & 0,721 & 0,705 & 0,663 & 0,734 & 0,692 & 0,664 & 0,806 \\
\hline LPI & $1,06 \mathrm{E}-05$ & 0,04138 & 100 & 0,623 & 0,61 & 0,531 & 0,651 & 0,575 & 0,573 & 0,663 \\
\hline
\end{tabular}

\subsection{Metot}

Çalışmanın bu bölümünde LPI tahmin modellemesinde kullanılan yöntemlerden bahsedilmektedir. Modellemelerde yapay zekâ tekniklerinden yapay sinir ağları (YSA) ve uyarlanabilir sinirsel bulanık çıkarım sistemi (ANFIS), istatistiksel yöntemlerden ise çoklu doğrusal regresyon (MLR) yöntemleri tahmin modellemesinde kullanılmaktadır.

İstatistiksel bir yöntem olan regresyon analizi değișkenler arasındaki sebep-sonuç ilișkisinin belirlenmesinde kullanılmaktadır [22]. Bağımsız değişkenlerin bağımlı değişkenler üzerindeki etkisi katsayılar ile ifade edilir. Bu katsayı, regresyon katsayısıdır ve değişkenin bağlılık derecesini göstermektedir. Bu çalışmada, MLR tekniklerinden doğrusal, etkileşimli, karesel ve basit karesel regresyon kullanılmaktadır.

ANFIS yöntemi; YSA ve bulanık mantık yöntemlerinden oluşan hibrit bir modeldir. Bulanık çıkarım sistemi (FIS) üç ana gruba ayrılmaktadır: Mamdani, Sugeno, Tsukamato [23]. Bulanık sistemlerin temel yapısı olan üyelik fonksiyonlarının uygun şekilde seçilmesi ANFIS performansına bağlıdır. Öğrenme yeteneğiyle YSA hem bulanık kümelerin üyelik fonksiyonlarının en iyi parametrelerini bulmak için hem de FIS' in bulanık kurallarını oluşturmak için sistematik bir süreç sunabilmektedir [24]. ANFIS yapısı Şekil 3'te gösterilmektedir. "X1, X2, X3,...,Xn"; "A11,..,An2"; "П"; "N" ve "wi" sirasıyla girdi parametrelerini, üyelik fonksiyonlarını, kuralları, kullanılan modellemede sisteme uygulanan bulanık kurallardan sonra parametrelerin ağırlığını temsil etmektedir.

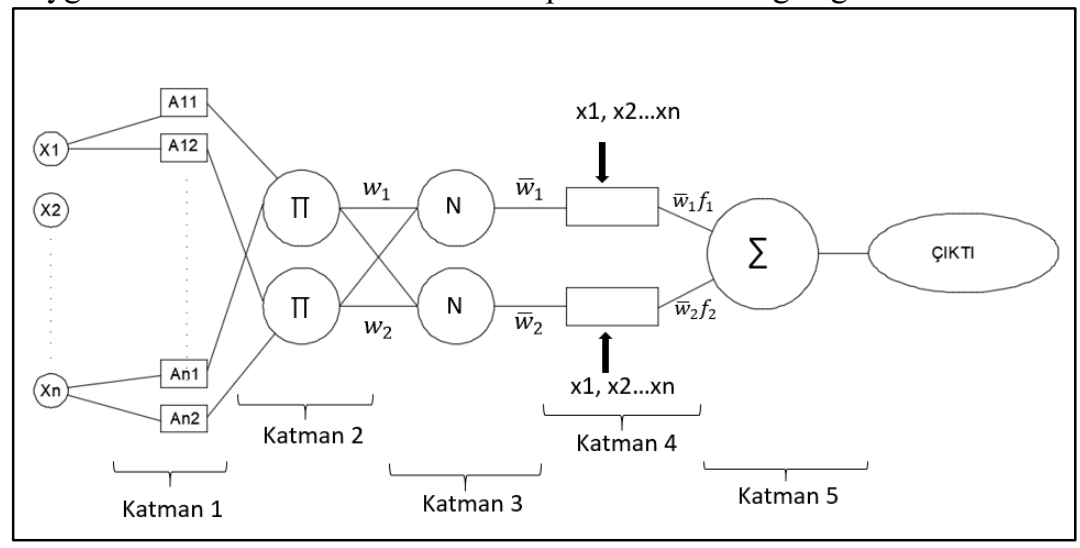

Şekil 3. ANFIS genel model yapısı

Bu çalışmada, ANFIS modelinin üyelik fonksiyonu (MF) sayısı her bağımsız değişken için ikidir. Modelin MF tipi gauss (gaussmf) üyelik fonksiyonudur. Gaussmf üyelik fonksiyonunun matematiksel formülü denklem 1 'de verilmektedir. Burada f çıktıyı, x girdiyi, $\sigma$ standart sapmayı ve c ise ortalamayı temsil etmektedir [25].

$$
f(x ; \sigma, c)=e^{\frac{-(x-c)^{2}}{2 \sigma^{2}}}
$$

YSA yöntemi, doğrusal olmayan ilişkili problemlerde birçok istatistiksel ve yapay zekâ yöntemine kıyasla yüksek performans göstermektedir. Bir YSA modelinde, her giriş farklı ağırlıklarla çarpılmakta, daha sonra transfer fonksiyonu ile işlenmekte ve bir sonraki katmandaki nöronlara aktarılmaktadır. Bu işlemler ağdaki katman sayısına 
Yapay Zekâ ve İstatistiksel Yöntemler ile Küresel Ticarette Rekabet Ölçütü Olan Lojistik Performans İndeksine (LPI) Etken Parametrelerin Ülke Bazlı İncelenmesi ve Tahmin Modellerinin Geliştirilmesi

bağlı olarak tekrarlanmaktadır. Her katmanda ağ modeli geliştirmek için yeni ağırlıklar atanarak ağın öğrenmesi gerçekleştirilmektedir [22]. YSA yönteminin avantajlarının yanı sıra dezavantajları da bulunmaktadır. YSA yönteminde, ağırlıkların atanması kara kutu mantığına dayanmaktadır. Yani, ağırlıkların nasıl atandığı bilinmemektedir [26].

$\mathrm{Bu}$ çalışmada, tek gizli katmanı olan YSA modelleri oluşturulmaktadır. Yaygın olarak kullanılan MATLAB eğitim algoritmalarından gradient descent backpropagation (GD), gradient descent with momentum backpropagation (GDM), Levenberg-Marquardt backpropagation (LM) ve resilient backpropagation (RP) kullanılmaktadır. Dört eğitim algoritmasından en iyi sonucu LM algoritması vermektedir. Şekil 4'te en iyi YSA modelinin ağ yapısı görülmektedir. Gizli katmanında tansig ve çıkış katmanında purelin transfer fonksiyonu kullanılmaktadır. Ayrıca ağın gizli katmanında 3 nöron kullanılmaktadır. En iyi modelin eğitim süreci ve MSE grafikleri Şekil 5 'te verilmiştir.

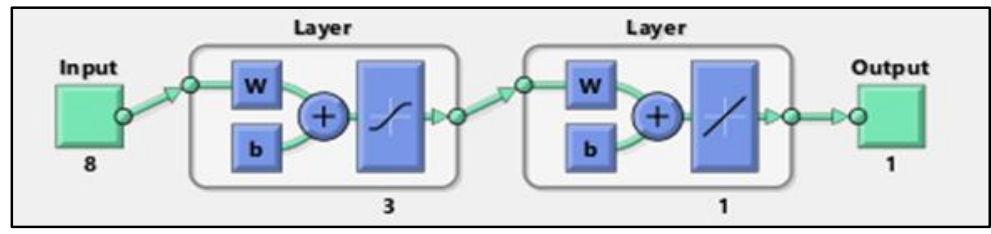

Şekil 4. En iyi YSA modelinin ă̆ yapısı
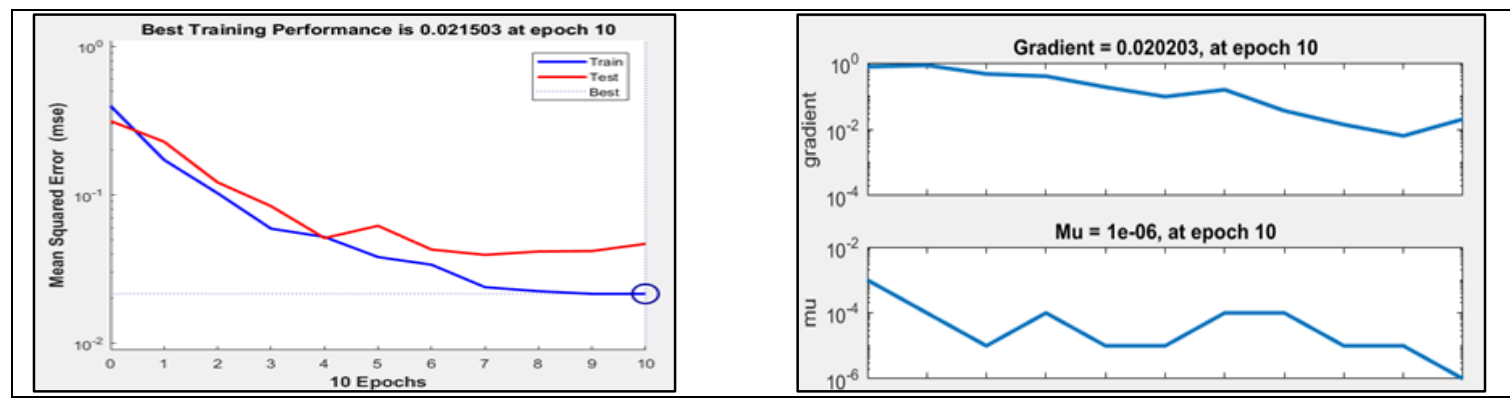

Şekil 5. En iyi YSA modelinin epoch sayısına göre HKO değişimi ve en iyi YSA modelinin eğitim süreci

\section{Sonuçlar ve Tartışma}

Altı farklı teknikle oluşturulan tahmin modellerinin en iyi model sonuçları şekil 6, 7, 8, 9, 10 ve 11 'de gösterilmektedir.

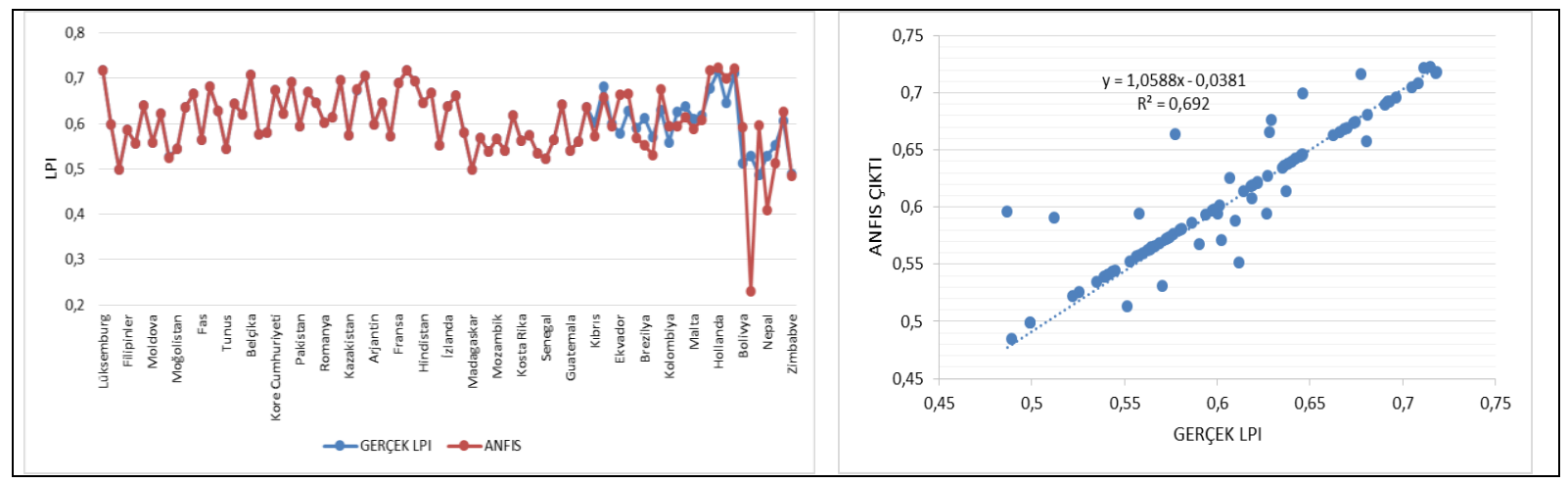

Şekil 6. Gerçek LPI değerleri ile ANFIS model sonuçlarının karşılaştırılması ve ANFIS model sonuçları ile gerçek LPI değerlerinin saçılım grafiği 


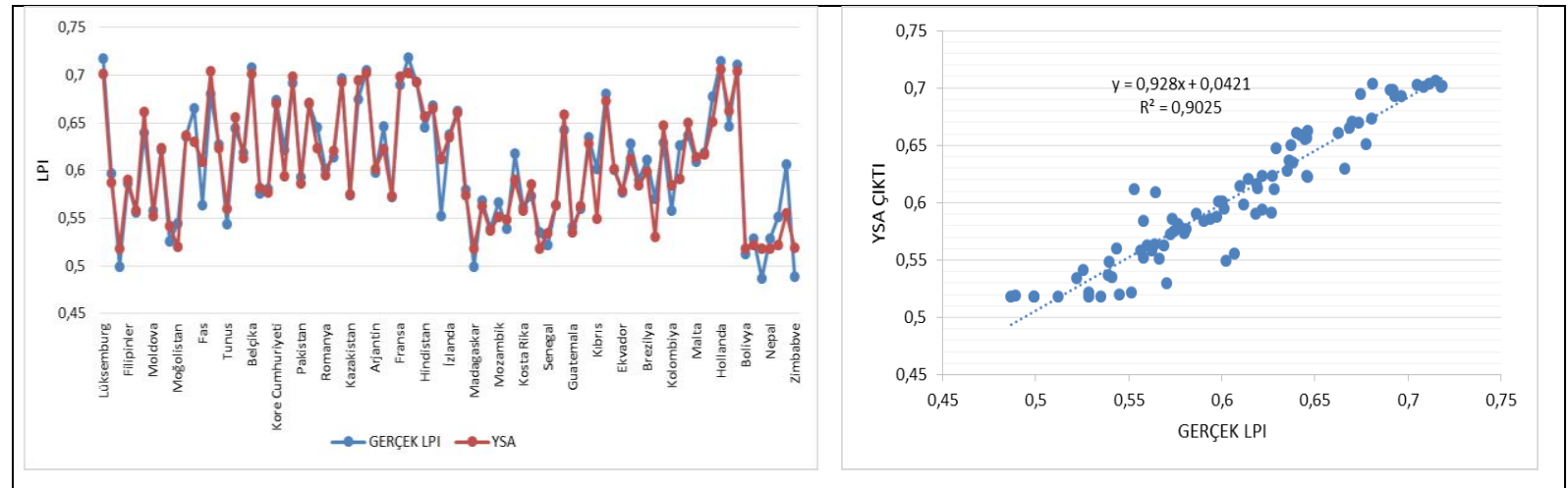

Şekil 7. Gerçek LPI değerleri ile YSA model sonuçlarının karşılaştırılması ve YSA model sonuçları ile gerçek LPI değerlerinin saçılım grafiği

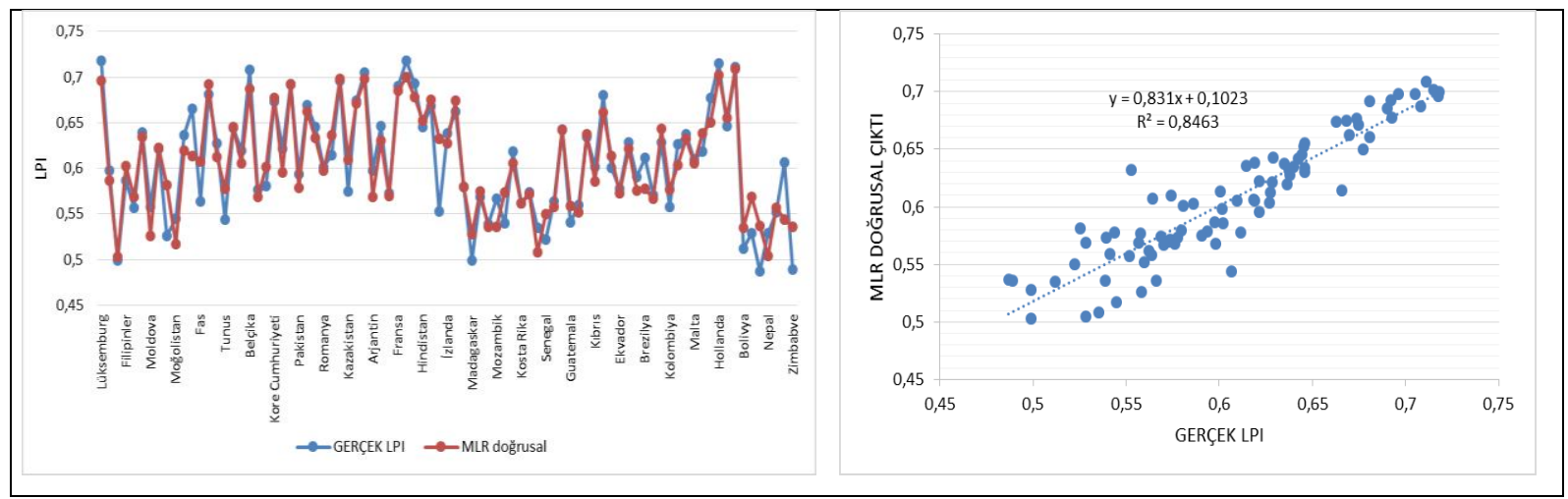

Şekil 8. Gerçek LPI değerleri ile MLR doğrusal model sonuçlarının karşılaştırılması ve MLR doğrusal model sonuçları ile gerçek LPI değerlerinin saçılım grafiği

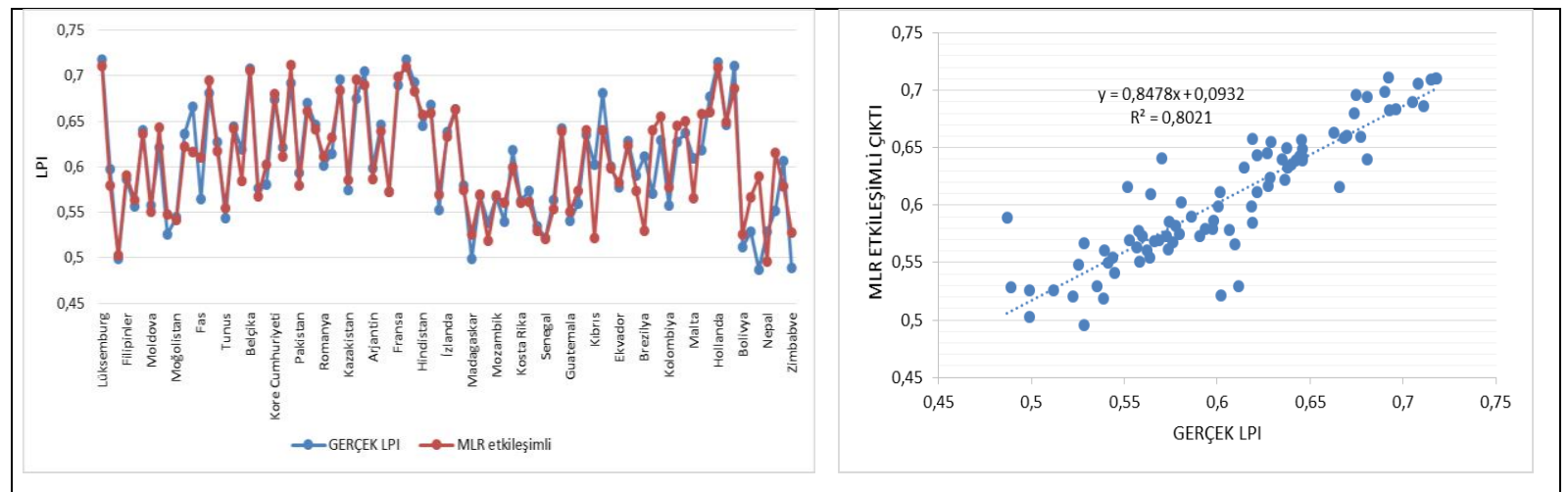

Şekil 9. Gerçek LPI değerleri ile MLR etkileşimli model sonuçlarının karşılaştırılması ve MLR etkileşimli model sonuçları ile gerçek LPI değerlerinin saçılım grafiği 

Ülke Bazlı İncelenmesi ve Tahmin Modellerinin Geliştirilmesi

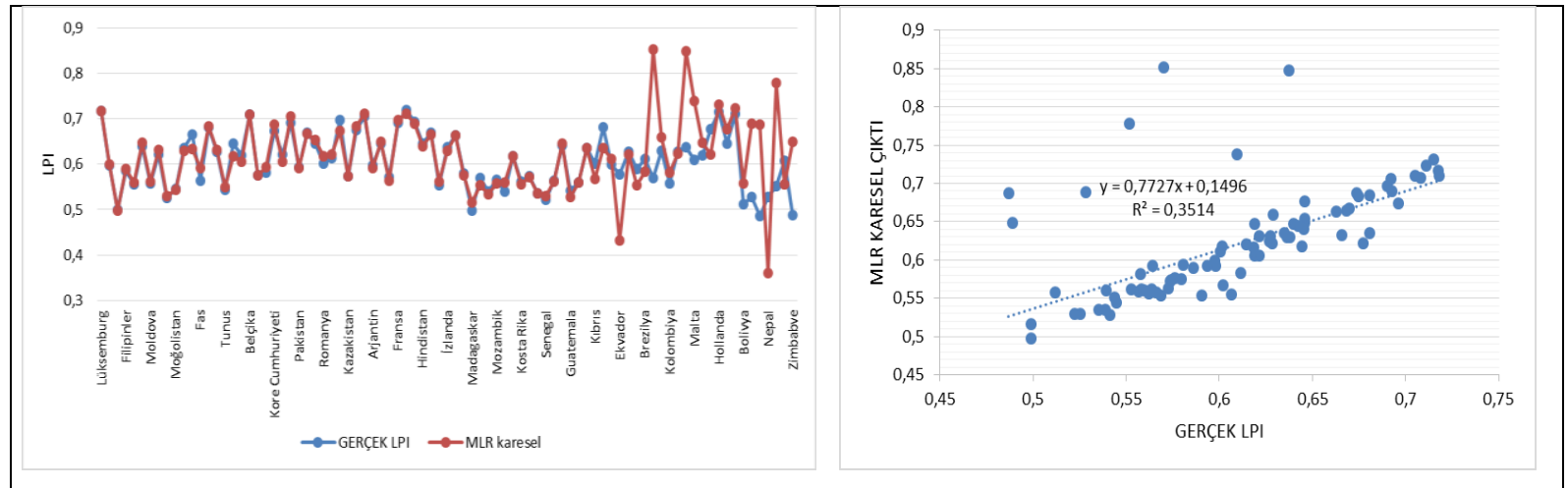

Şekil 10. Gerçek LPI değerleri ile MLR karesel model sonuçlarının karşılaştırılması ve MLR karesel model sonuçları ile gerçek LPI değerlerinin saçılım grafĭği

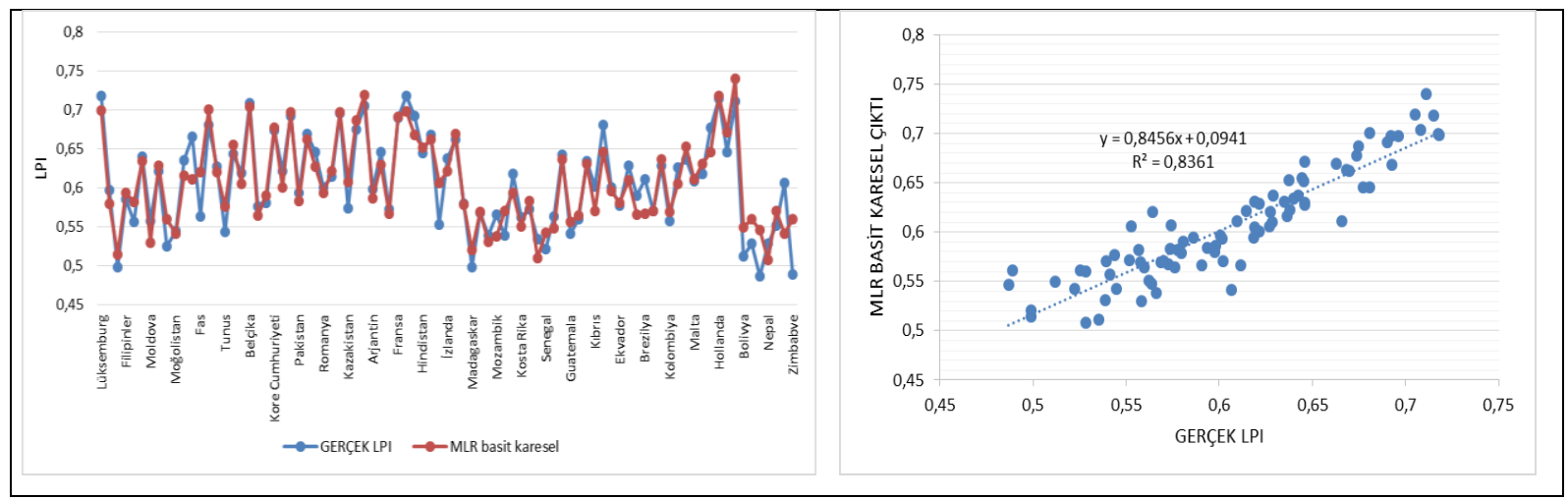

Şekil 11. Gerçek LPI değerleri ile MLR basit karesel model sonuçlarının karşılaştırılması ve MLR basit karesel model sonuçları ile gerçek LPI değerlerinin saçılım grafiği

Altı teknik ile geliştirilen modellerden en iyi performansa sahip model YSA modelidir. En iyi YSA modelinin eğitim ve test periyotlarına göre ilişki grafikleri Şekil 12'de verilmektedir. MATLAB programında yapılan analiz sonucunda en iyi YSA modelinin ağırlık ve taban değerleri alınmış ve Denklem 2'de YSA formülü oluşturulmaktadır.

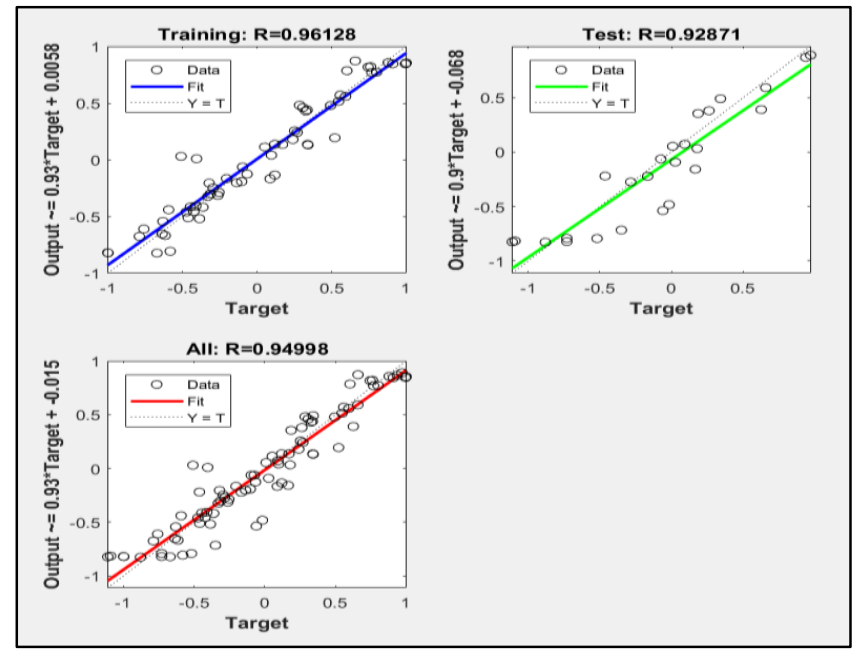

Şekil 12. En iyi YSA modelinin eğitim ve test sonuçlarının ilişki grafikleri 


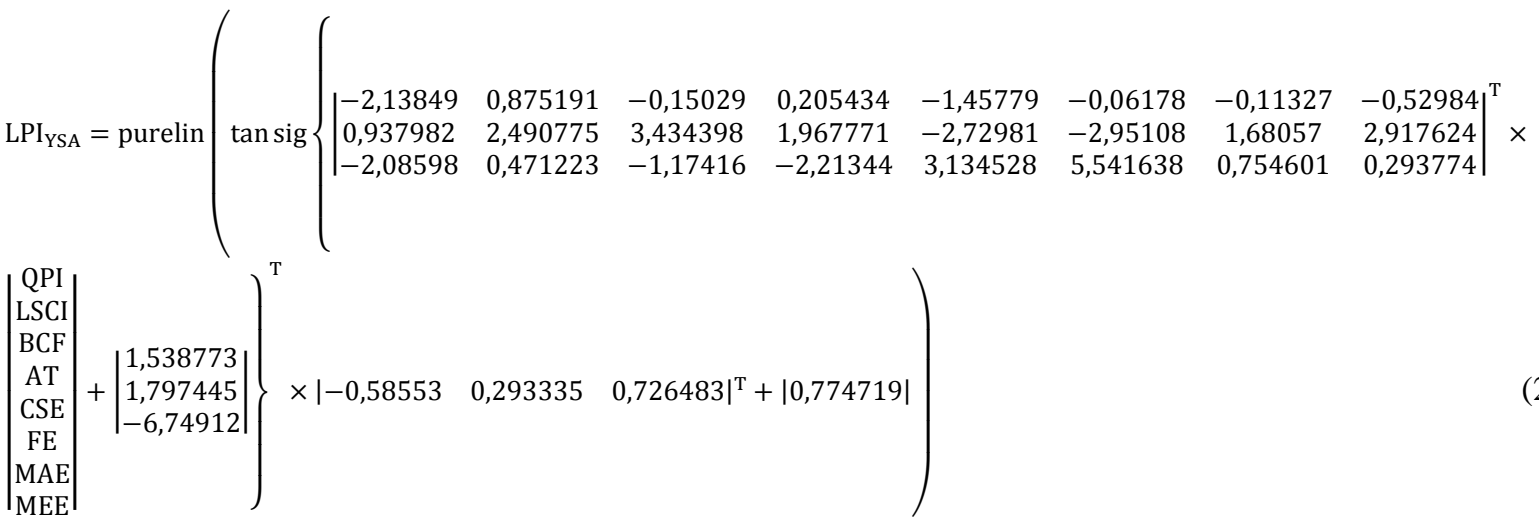

Performans değerlendirme kriterleri her model için hesaplanmaktadır. Performans kriterleri hataların karesinin ortalaması $(\mathrm{HKO})$, ortalama yüzde hata $(\mathrm{OYH})$ ve model sonuçları ile gerçek LPI değerleri arasındaki ilişkiyi gösteren korelasyon katsayısıdır (R). HKO ve OYH eşitlik 3 ve 4’teki gibi verilmektedir.

$$
\begin{aligned}
& M S E=\frac{1}{N}\left(\sum_{i=1}^{N} Y_{i(\text { real })}-Y_{i(\text { estimated })}\right)^{2} \\
& M S E=\frac{1}{N}\left|\sum_{i=1}^{N} Y_{i(\text { real })}-Y_{i(\text { estimated })}\right|
\end{aligned}
$$

Altı modelin performans kriterleri Tablo 7'de verilmektedir. Performans değerleri incelendiğinde karşılaştırma grafikleri ile tutarlı sonuçlar elde edilmektedir. En az hata miktarı YSA modelinde görülmektedir. YSA modelinin R, MSE ve MPE değerleri sirasiyla \% 94,998, 0,00035 ve \%1,35'dir. YSA den sonra en iyi model, 0,00054 HKO ve \%91,994 R ile MLR doğrusal modelidir. En kötü performansa sahip model ise \%59,28 ilişki ve 0,00419 HKO ile MLR karesel modelidir.

Tablo 7. Tahmin modellerinin performans sonuçları

\begin{tabular}{llll}
\hline & R & HKO & OYH(\%) \\
YSA & 0,94998 & 0,00035 & 1,35 \\
ANFIS & 0,83185 & 0,00177 & 1,49 \\
MLR doğrusal & 0,91994 & 0,00054 & 1,73 \\
MLR etkileșimli & 0,89561 & 0,00071 & 1,81 \\
MLR karesel & 0,59280 & 0,00419 & 3,05 \\
MLR basit karesel & 0,91438 & 0,00058 & 1,84 \\
\hline
\end{tabular}

\section{Sonuçlar}

Bu çalışmada ülkelerin küresel ölçekte lojistikteki önemini belirleyen lojistik performans indeksi(LPI) ve performans indeksine etken değişkenler üzerinde durulmaktadır. Çalışmanın ilk aşamasında LPI'ne etken parametrelerin ne ölçüde etkili olduğu kümeleme, SIMPER analizleri ile ortaya konulmaktadır. Analiz sonucunda LPI'nde en etkili parametrenin AT olduğu ortaya konulmaktadır. Ayrıca ülkelerin belirlenen parametrelere göre sınıflandırılmasında da AT parametresinin en etkili olduğu göze çarpmaktadır. Çalışmanın ikinci bölümünde LPI'ne etken parametreler dikkate alınarak tahmin modelleri oluşturulmaktadır. Tahmin modellerinin karşılaştırılmasında HKO, OYH, R performans kriterleri dikkate alınmaktadır. Buna göre en iyi performansa sahip tahmin modeli YSA yöntemi ile oluşturulan modeldir.

$\mathrm{Bu}$ çalışmadan elde edilen LPI denklemleri dikkate alınarak, ülkelerin liman altyapı kalitesi, layner taşımacılığı bağlantı endeksi, gümrük giderleri, havayolu yük taşımacılığı, ticari hizmet ihracatı, gıda ihracatı, imalat ihracatı ve mal ihracatı göstergelerine bağlı olarak geleceğe yönelik ülkelerin lojistik performansları hakkında bilgi sahibi olacakları düşünülmektedir. Ayrıca ortaya konan denklemler sayesinde eşit ağırlıklı olarak belirlenen LPI değeri yerine farklı ağırlıklarda girdiler ile yeni LPI değeri belirlenmektedir. Bunun yanı sıra anket usulü belirlenen sübjektif LPI değeri yerine, bu çalışmadan elde edilen denklemler ile ülkelerin lojistik performans ölçütleri dikkate alınarak daha objektif LPI değerine ulaşılacağı düşünülmektedir. 


\section{Referanslar}

[1] Bayraktutan Y, Tüylüoğlu Ş, Özbilgin M. Lojistik sektöründe yoğunlaşma analizi ve lojistik gelişmişlik endeksi: Kocaeli örneği. Journal of Alanya Faculty of Business/Alanya Isletme Fakültesi Dergisi 2012; 4(3): 61-71.

[2] Gergin R E, Baki B. Türkiye'deki bölgelerin lojistik performanslarının bütünleştirilmiş AHS ve TOPSIS yöntemiyle değerlendirilmesi. Business \& Economics Research Journal 2015; 6(4): 115-135.

[3] Çemberci M, Civelek ME, Canbolat N. The moderator effect of global competitiveness index on dimensions of logistics performance index. Procedia-Social and Behavioral Sciences 2015; 195, 1514-1524.

[4] Martí L, Puertas R, García L. The importance of the Logistics Performance Index in international trade. Applied Economics 2014; 46(24), 2982-2992.

[5] Ulutaş A, Karaköy Ç. An analysis of the logistics performance index of EU countries with an integrated MCDM model. Economics and Business Review 2019; 5(4): 49-69.

[6] Başar SI, Bozma G. (2017). Ülkelerin Lojistik Performanslarının Belirleyicileri. Kafkas Universitesi. Sosyal Bilimler Enstitu 2017; (20), 447-458.

[7] Güner S ve Coskun E. Comparison of impacts of economic and social factors on countries' logistics performance: a study with 26 OECD countries. Research in Logistics and Production 2012; 2(4): 329-343.

[8] Uca N, Civelek M E, Cemberci M. The effect of the components of logistics performance index on gross domestic product: conceptual model proposal. Eurasian Business\&Economics Journal 2015;1: 86-93.

[9] Karaköy Ç, Üre S. Yüksek ve orta gelirli ülkelerde büyüme ve lojistik performans endeksi arasındaki ilişki. Al Farabi 4. Uluslararası sosyal bilimler kongresi Erzurum. 2019; 575-580, Erzurum.

[10] Jhawar A, Garg SK, Khera SN. Analysis of the skilled work force effect on the logistics performance index - case study from India. Logistics Research 2014; 7(1), 117.

[11] https://www.indexmundi.com/facts/indicators/IQ.WEF.PORT.XQ (10.10.2019)

[12] https://datacatalog.worldbank.org/liner-shipping-connectivity-index-maximum-value-2004-100 (10.10.2019)

[13] https://datacatalog.worldbank.org/burden-customs-procedure-wef-1extremely-inefficient-7extremely-efficient (10.10.2019)

[14] https://datacatalog.worldbank.org/air-transport-freight-million-ton-km-1 (10.10.2019)

[15] https://www.imf.org/external/np/sta/bop/bopman.pdf (10.10.2019)

[16] https://datacatalog.worldbank.org/search?search_api_views_fulltext_op=AND\&query=Commercial\%20service\%2 0exp orts\%20(current\%20US\$)\&nid=\&sort_by=search_api_relevance\&sort_order=DESC (10.10.2019)

[17] https://www.indexmundi.com/facts/indicators/TX.VAL.FOOD.ZS.UN (10.10.2019)

[18] https://datacatalog.worldbank.org/manufactures-exports-merchandise-exports-0 (10.10.2019)

[19] https://www.indexmundi.com/facts/indicators/TX.VAL.MRCH.CD.WT (10.10.2019)

[20] https://www.indexmundi.com/facts/indicators/LP.LPI.OVRL.XQ (10.10.2019)

[21] https://www.worldbank.org/ (10.10.2019)

[22] Dal K, Cansiz OF, Ornek M, Turedi Y. Prediction of footing settlements with geogrid reinforcement and eccentricity. Geosynthetics International 2019; 26 (3): 1-12.

[23] Unes F, Joksimovic D, Kisi O. Plunging flow depth estimation in a stratified dam reservoir using neuro-fuzzy technique. Water Resour. Manage 2015; 29: 30055-3077.

[24] Jang JSR, Sun CT, Mizutani E. Neurofuzzy and soft computing: a computational approach to learning and machine intelligence IEEE Transactions on Automatıc Control 1997; 42(10): 1482-1484.

[25] https://www.mathworks.com/help/fuzzy/gaussmf.html (21.11.2019)

[26] Karayiannis N, Venetsanopoulos A N. (2013). Artificial neural networks: learning algorithms, performance evaluation, and applications (Vol. 209). Springer Science \& Business Media. 